\title{
SEDIMENTOLOGICAL AND GEOPHYSICAL OBSERVATIONS IN THE DELTA PLAIN OF SELINOUS RIVER, ANCIENT HELIKE, NORTHERN PELOPONNESUS GREECE
}

\author{
Koutsios A. ${ }^{1}$, Kontopoulos N. ${ }^{1}$, Kalisperi . $^{2}$, Soupios P. ${ }^{2}$ and Avramidis P. ${ }^{3}$ \\ 1 University of Patras, Department of Geology, Laboratory of Sedimentology, 26500 Patras, Greece, \\ 2 Technological Educational Institute of Crete, Laboratory of Geophysics and Seismology, \\ 3 Romanou, Chalepa 73133 Chania, Greece \\ 3 Technological Educational Institute of Mesolonghi, Laboratory of Geology of Aquatic Systems, \\ Nea Ktiria 30200 Mesolonghi Greece.
}

\begin{abstract}
Fine and coarse grained lithofacies and depositional environments were distinguished in Selinous River delta plain, from sediment cores using an Eijkelkamp percussion corer with barrel windows. The sedimentary sequence of deltaic plain deposits of Selinous River mostly consists of fine lithofacies interbedded occasionally with conglomerate facies. Fine grained lithofacies based on sediment types, structure, color, as well as contact depths and bed characteristics were interpreted as floodplain, crevasse splay, back swamp / fresh water swamp, permanent shallow fresh water lake and ephemeral fresh water lake facies. The coarse grained lithofacies consists of pebble - conglomerates and were interpreted as paleochannels. The Time-Domain Electromagnetic technique, (TEM) was applied in order to define the spatial distribution of lenses of conglomerates, palaeochannels and fine grained sedimentary material to be recognised, at a depth up to $35 \mathrm{~m}$. Both the sedimentological and geophysical approaches, in combination with the available geological and geomorphological data of the area, can provide information about the evolution, existence and the geometry of paleochannels of the Selinous River flood plain, and the paleoenvironment of the area of the ancient Helike.
\end{abstract}

Key words: Selinous River, delta plain, depositional environments, TEM, ancient Helike.

\section{Introduction}

On the southwest shore of the Gulf of Corinth, deposits from Selinous and Kerynites Rivers form a low delta plain. During the winter of 373 BC, according to historical sources the Helike city was destroyed by a strong earthquake tsunami and rapidly submerged (Katsanopoulou, 2005). The city was the capital of the "Achaean Dodecapolis". During the last fifty years many Greek and foreigner scientists tried to interpret the way of destruction and the locality of ancient Helike. The paleogeographic evolution of the delta plain may be the key to be recognized the mechanisms of the destruction and the geographical location of the city. In order to reconstruct the evolution of the Selinous and Kerynites delta plains, sedimentological and geophysical data were intergrated. Sedimentological data were obtained from the detailed description of several boreholes of the area (Koutsios, 2009) while geophysical data where based on the application of the Time-Domain Electromagnetic technique. 


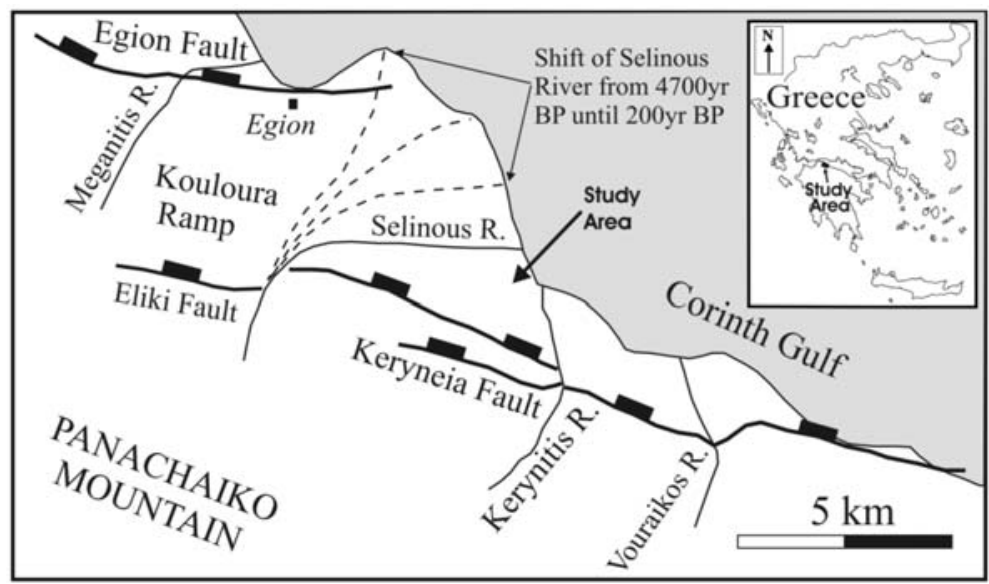

Fig. 1: Map showing the location of the study area, Selinous and Kerynitis Rivers, the major fault systems of the area (Koukouvelas \& Doutsos 1996; Koukouvelas 1998) and the shift of Selinous river flow from a NNE to a ENE course (Kontopoulos \& Avramidis 2003).

The Time-Domain ElectroMagnetic technique, (TEM) is a relatively recent method, as it has been used in environmental and hydrogeological studies (Soupios et al. 2009; Kalisperi 2009) in the last 15-20 years. An analytical presentation of the method can be found by McNeill (1994), and Nabighian and Macnae (1991), whereas a brief description of the method is provided. The TEM method makes use of a direct current transmitted into the transmitter loop lying on the ground. The current creates a primary, stationary magnetic field. The direct current is switched off which induces an eddy current system in the ground. Due to ohmic resistance of the subsurface, the current system will decay and further induce a secondary magnetic field that is measured in an induction coil (the receiver coil). The decay rate of the electromagnetic field depends on the resistivity distribution of the subsurface.

The main purpose of this study is to contribute in understanding of the paleogeographic evolution of the Selinous delta (Ancient Helike) plain during late Holocene times, examining its subsurface geology with sedimentological and geophysical approach. TEM method is used in this study, for a very detailed survey since the target (lenses of conglomerates, paleochannels and other depositional materials) is very shallow and has very limited size.

\section{Geological setting}

The study area is located between the Selinous and Kerynites Rivers in the north Peloponnesus, Greece. The largest part of the study area is characterized by the presence of five WNW-trending normal extensional faults dipping to the north (Koukouvelas \& Doutsos 1996). Two of these, the Helike and Egion faults, are the northernmost that affect the south coast of the Gulf of Corinth (Fig. 1).

A thick sequence of fan delta sediments of the Selinous river that accumulated on the Heliki hanging wall block during the late Quaternary, evolved under the influence of long-term tectonic uplift and earthquake-related subsidence (Soter, 1998). Also, Pleistocene and modern fan deltas were deposited in the hangingwall basin of the Egion fault (Poulimenos, 1993).

Modern fan delta sediments are supplied from the Meganitis river and occur towards the central portion of the fault. Towards both ends of the Egion fault, progressive emergence of the hangingwall 


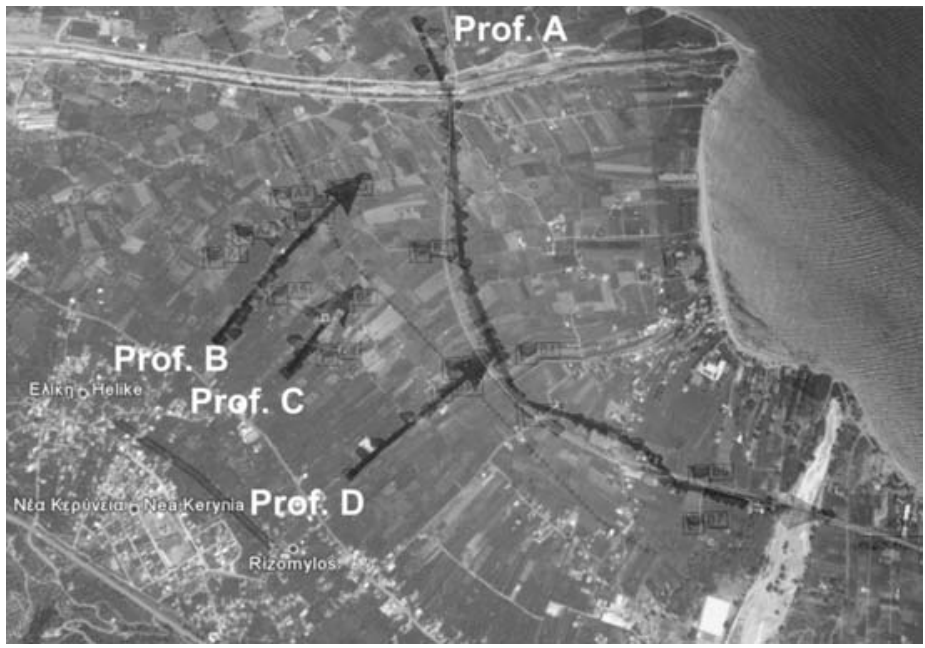

Fig. 2: Map showing, The Selinous and Kerynitis Rivers, the location of the boreholes (A1-A6 and B1-B10) and the geophysical profiles (A, B, C, \& D). Note that, Profile A was acquired along the local railway.

basin is testified by the development the Meganitis and Selinous coastal alluvial plains (Koukouvelas, 1998). The Egion and Eiki faults are separated by the eastward - tilted Kouloura ramp (Fig. 1). The Kouloura ramp developed under competition between uplift of the Egion footwall and subsidence of the Heliki hangingwall areas (Koukouvelas, 1996). This ramp has induced the historical shift of the Selinous river flow from a NNE to a ENE course (Kontopoulos \& Avramidis 2003).

\section{Methods}

Sediment cores A1-A6 and B1-B10 were obtained using an Eijkelkamp percussion corer with barrel windows (Fig. 2). Sediment types, structure, color, as well as contact depths and bed characteristics were recorded for each core in the field. The approximate percentage of shell fragments, plant remains, carbonate cemented grains concretions and terrigenous grains in the sand fraction were estimated visually. Radiocarbon dating was carried out in selected samples (shells and organic material) at Beta Analytic, Miami (Fig. 3).

In this work, an innovative application of TEM technique (Missiaen et al. 2008) was attempted, using single loop $12.5 \times 12.5 \mathrm{~m}$ for very shallow-depth (less than 30 meters) paleogeographical mapping in the broader area of Heliki village (Northern Peloponnesus), Greece was conducted. In total, one hundred ninety-five (195) TEM soundings were acquired in one hundred twenty-one (121) different locations (Fig. 2). The study area is located into the flood plain of Heliki area and is bounded by the Selinous River (to the North) and Kerynitis River (to the South), the Heliki's fault (to the West) and the coast line (to the East). Since the paleochannels are expected to develop in a SW-NE direction (parallel to the rivers), a very detailed NW-SE TEM profile (Prof. A) with about 5-50m interval between the measurements, was conducted. Three supplementary sub-parallel profiles were acquired in a SW-NE direction within the flood plain (Profiles B, C and D; Fig. 2), for comparison with the geophysical images.

During the geophysical fieldwork, the team was very careful for the optimum site selection, the installation of the antenna, and other environmental conditions which can produce noisy and bad qual- 
ity data. The root mean square (rms) error of the final data set was mainly less than $8 \%$. The system was set to transmit current up to 4 Amp with 28 active time gates from $4 \mu$ s to $512 \mu$ s and the parameter "stack", which corresponds to the digital stacking of a signal, was set to 5 (each number of this parameter corresponds 13 complete cycles). To define and avoid aliasing effects (high frequency - HF noise from radio sources) the measurements were repeated several times at each sounding location.

Data processing provided the one dimensional (1D) distribution of resistivity with depth. The TEMRESearcher, a Windows integrated software system, was the tool for data processing of TEM data and inverse problem solution (TEM-RESearcher manual 2007). Raw data were "edited" (e.g. first points were excluded from the curve for further analysis) and "smoothed" before modelling, as the manufacturer suggests (Barsukov et al. 2007). TEM-RES software provides two ways to elaborate a section, transformation and inversion. Since the $1 \mathrm{D}$ modelling is inadequate to reconstruct and describe the subsurface, 2D imaging is demanded. TEM-RES software is a great tool for geoelectrical sections construction as well. Thus, the 1D inversion data are received and the user can choose any profile he prefers to illustrate.

\section{Results}

\subsection{Sedimentology}

The sedimentary sequence of the deltaic plain deposits of Selinous River mostly consists of fine lithofacies interbedded occasionally with conglomerate facies. According to Koutsios (2009), the stratigraphy and the interpretation of the paleoenvironments, based on the data from the boreholes A1-6 and B1-B10 (fig. 1), is presented in figures 3 and 4. The fine and coarse grained facies identification criteria and interpretation are as follows:

\section{FINE - GRAINED LITHOFACIES}

A. Floodplain facies: Constist of silty and clayey sediments, dark yellow or brown in colour, poorly to very poorly sorted and incidentally extremely poorly sorted, with positive to very positive skewness. The CM segments refer to VII, VIII, IX, and III. Massive bedding, horizontal bedding, horizontal lamination, cross-lamination, normal graded bedding, convolute lamination, have been observed. Occasionally present of ostracod fragments and more often gastropod fragments. Thickness of individual beds is of the order of a few millimeters up to a few centimeters or tens of centimeters according to the size of the flood event.

$\mathrm{A}_{1}$. Proximal floodplain facies: Are characterized by the increasing presence of silt in relation to clay and sand fraction.

$\mathrm{A}_{2}$. Distal floodplain facies: Predominance of clay in relation to the silt fraction. The coarser lithology is few up to absent.

$\mathrm{A}_{3}$. Pond facies: Pedogenetic characters (5\%-15\%). Calcite concretions formed around rootlets or caliche nodules.

B. Crevasse splay facies: Consist of gravelly and sandy sediments interbedded with the floodplain deposits. It is characterized by poorly to very poorly sorting and positive to very positive skewness. The CM segments refer to I, II and V fields. Small scale fining- upward sequences are present.

C. Back swamp facies/fresh water swamp facies: Consist of mud and clay sediments, gray or brown in colour, poorly to very poorly sorted with near symmetrical to positive skewness. The 


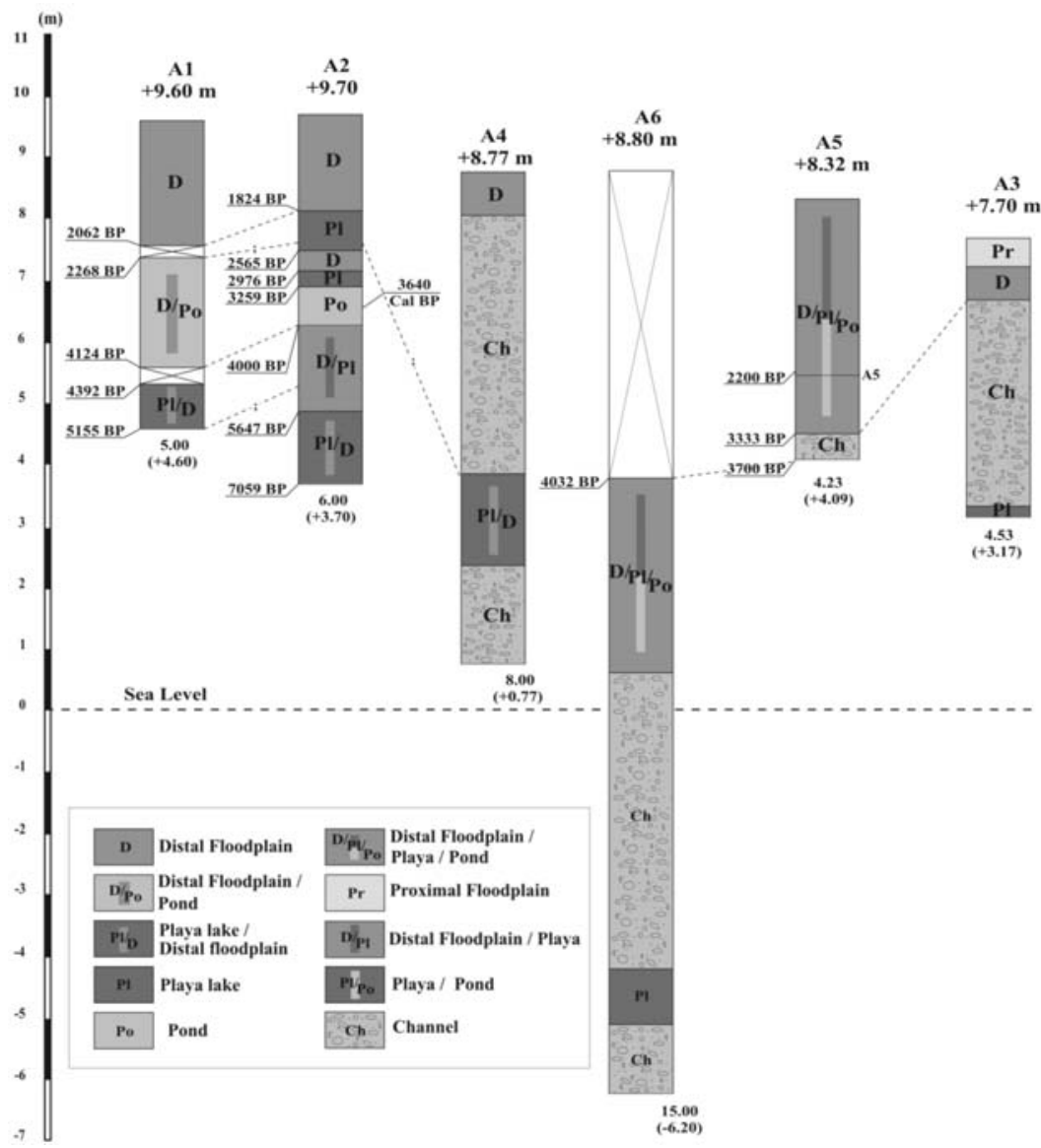

Fig. 3: Vertical profiles of boreholes A1-6, with the interpretation of depositional environments and the age estimation based on radiocarbon data (Koutsios, 2009).

CM segment correspond to VII field. Structures are absent. The sand fraction has a high concentration of plant remains and organic material. There is a significant presence of the fresh water Ostracodes (Candona) and gastropods (Planorbis, Pisidiun, Bithynia, Valvata, Limnea) and oogonia of the charophytes.

D. Permanent shallow fresh water lake facies: Consist of fine grain size sediments, gray or brown in colour, very poorly sorted with positive to very positive skewness. The CM segment correspond to VIII field. Massive structure or lamination has been observed. The sand fraction has a low concentration of plant remains, as well as calcite concretions and organic material. Significant presence of the fresh water ostracodes (Candona, Ilyocypris), gastropods (Bithynia, Valvata, Limnea) and oogonia of the charophytes has been observed.

E. Ephemeral fresh water lake facies: Consist of fine-grain sediments, gray, brown or orange in colour, very poorly sorted with positive to very positive skewness. The sand or silt content is often considerably. The CM segment correspond VII, VIII and T. Massive structure or lamination is present. Significant presence of the fresh water ostracodes (Candona, Ilyocypris), gastropods (Planorbis, Bithynia, Valvata, Limnea) and oogonia of the charophytes have been 


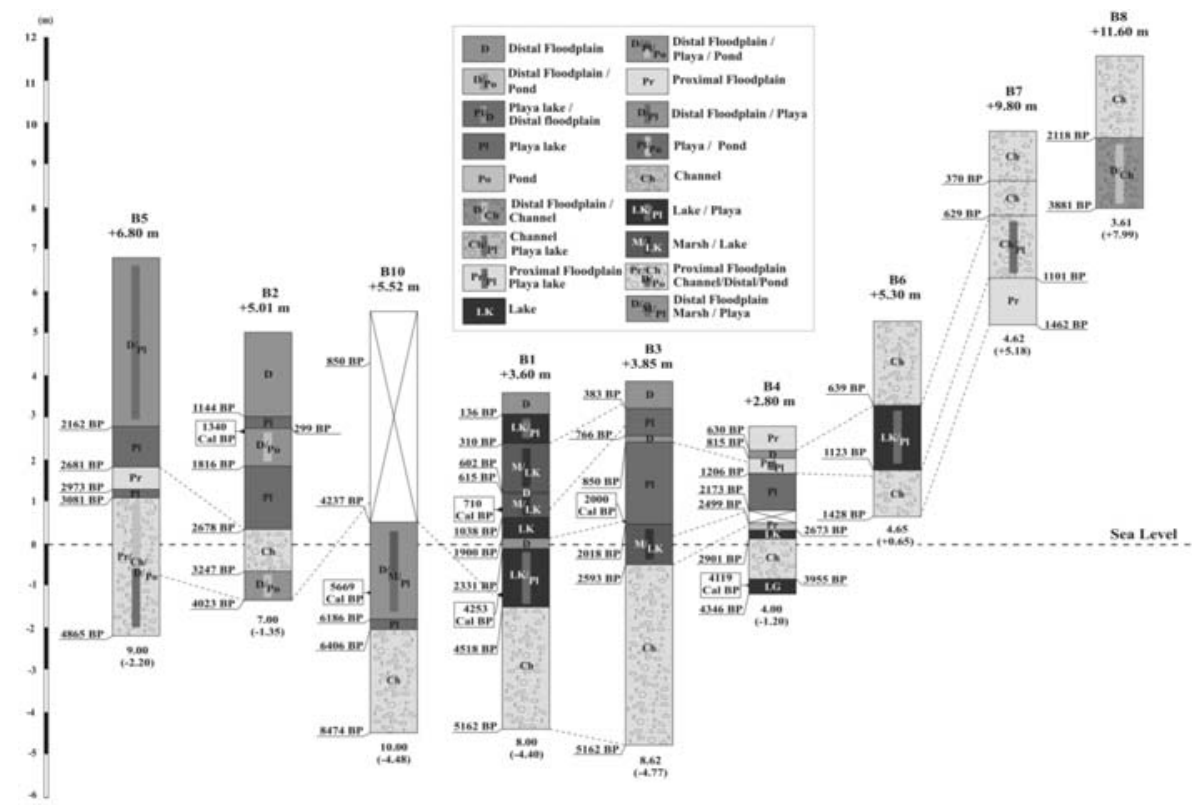

Fig. 4: Vertical profiles of boreholes B1-10, with the interpretation of depositional environments and the age estimation based on radiocarbon data (Koutsios 2009).

observed. Calcite concretions range between $15 \%$ and $100 \%$. There is a significant presence of manganese concretions and caliche nodules too.

\section{COARSE - GRAINED LITHOFACIES}

The coarse grained facies consists of pale yellow or brownish red pebble conglomerates. It has poorly to very poorly sorting and positive to very positive skewness. The conglomerates are represented by CM segments I, II, IV, and V. The structures generally are absent. Sometimes normal or reverse graded bedding is present. The organic matter and fossils are missing. There is an insignificant presence of reworked fossils.

\subsection{Geophysical Data Acquisition - Processing - Modelling}

Profile A is 2.695 meters long (Fig. 5) and was taken along the railway (Fig. 2) but in some distance to avoid contamination (noise) of the TEM measurements. The average depth of penetration was around 35 meters. Inside the riverbeds (in Selinous and Kerynitis Rivers) and in order to define the thickness of the sedimentation, 15 sounding using $25 \times 25 \mathrm{~m}$ loop were collected (maximum depth of about 75 meters). Moreover, in Kerynitis River, a 50x50m sounding was additionally carried out in order to provide clearly the thickness of the sediments (riverbed).

Along the tomographic image of Profile A, several lenses of unsaturated conglomerates (high resistivity areas defined by dotted ellipses) were found. The lenses are surrounded by fine grained clay (high conductivity-blue colours) materials. The average depth of these lenses is about 7-13 meters below the surface and the average width of the lenses is about 20-30 meters. In the areas of the river beds (the Selinous and Kerynitis Rivers), different depositional materials were found, respectively. In Kerynitis riverbed (to the South-East) a normal depositional sequence was defined (the di- 


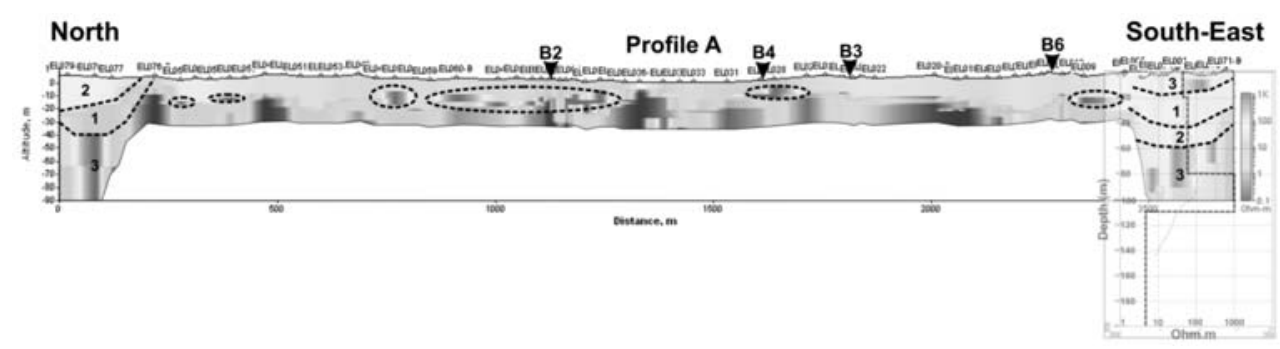

Fig. 5: Two dimensional imaging of the resistivity distribution in depth is given for Profile A. 1,2,3 are different facies of sedimentation (see text for more explanation). B\# are boreholes along the profile (see fig. 4) and black dashed ellipses depict the high resistive anomalies correlated with paleochannels.

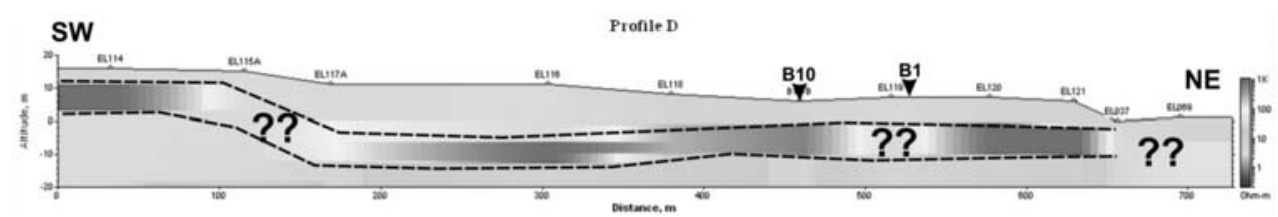

Fig. 6: Two dimensional imaging of the resistivity distribution in depth is given for Profile D (fig. 2). Question marks depict the discontinuities in the defined horizon. B\# are the boreholes (figs 3 and 4) along the profiles.

ameter/size of the grains are increased with depth), where conglomerates, sand and gravels (high resistivity-red colours) (facies 3, in Fig. 5) were defined at the bottom of the model and the sedimentation was continued to finer facies ( 2 and 1 in Fig. 5). As mentioned above, the results of the tomographic image was not very clear and one deep (till the depth of $150 \mathrm{~m}$ ) sounding was conducted proving that the depth to the bedrock (thickness of the riverbed) is 110 meters (stepwisedashed line). In Selinous riverbed (to the North), similar results were observed concerning the sedimentation but some changes in the deposition of the different lithological facies (2, 1 and 3), was found.

Profile D is $729 \mathrm{~m}$ long and is the most representative of the supplementary geophysical measurements which were acquired and as a result it was decided to present it as is shown in Figure 6. It can be assumed that, a paleochannel was defined (based on logs and after pers. com. with some expert geologists in sedimentology) along the collected measurements where the layer is not laterally persistent (question marks in Figure 6). This feature could be explained by changes in direction of the paleochannel. Based on the reconstructed tomographic model, the paleochannel seems to have the same thickness.

\section{Discussion and Conclusions}

A detailed geo-electromagnetic survey was carried out acquiring almost two hundred soundings in order to reconstruct the 2D subsurface resistivity distribution. This detailed survey in combination with the available sedimentological and paleogeographical data of the area is a useful tool for the determination of the major geomorphological shallow characteristics of the area under investigation. This work shows that a detailed study using a modern geophysical method (TEM-Transient Electromagnetic Method), can provide possible information about the existence and geometry of paleochannels of the flood plain and the paleoenvironment of the area of the ancient Heliki (between Selinous and Kerynitis Rivers). 
The lithostratigraphy of the delta plain is extremely heterogeneous as shown by Figures $3 \& 4$. This happened due to high variable deposition and erosion on a geologically active fan delta plain. Floods and shifting distributaries from the rivers produced a patchwork of fine and coarse deposits over much of the delta plain, until the Selinous and Kerynites Rivers were confined by levees about fifty years ago (Soter \& Katsonopoulou, 2005). The resulting lithostratigraphy varies, in the study area, greatly over horizontal scales of only a few meters as found in boreholes test excavations and geophysical research. Soter \& Katsonopoulou (2005) have shown the presence of a layer of coarse clastic material sand, gravel, pebbles or cobbles, usually more than a meter thick.

According to Soter \& Katsonopoulou (2005) the pebbles are generally angular and in some locations are more rounded. The above authors interpret the angular deposits as a terrestrial flood from the Katourla Fan (Fig 1), while the more rounded material as a marine beach which prograded and ascended with sea level rising. The lowest part of this coarse layer dates from about 7 to $8 \mathrm{kyr}$ BP.

Koutsios (2009) has shown the presence of layer from coarse-grained material proportional to this from Soter \& Katsonopoulou (2005). The detail sedimentology research of this material suggests a stream channel environment. The top of the layer has surface elevation about 3 meters and its low surface is approximately 5 meter below the present sea level (Figs. $3 \& 4$ ). The upper-most part dates from 2600 to $3000 \mathrm{BP}$ and the lowest part from 8000 to $8500 \mathrm{BP}$.

From SW to NE, at the beginning of the geophysical profile D up to the first discontinuity is shown the latest part of a channel emerging on to the Katourla fan surface (Fig. 6), while after the first discontinuity, there is another paleochannel at a lower level (Fig. 6). Both paleochannels are similar to the deposits, described by Soter \& Katsonopoulou (2005) and revealed by the bore holes B1-B10 from this study.

Profile A depicts the presence of several lenses of conglomerates located $130 \mathrm{~m}$ before and about $400 \mathrm{~m}$ after B2 borehole. Those lenses represent paleochannel cross-sectional areas and the coarse facies of the boreholes B1, B2, B3, B4 and B10. These are below the present sea level and at a depth of 4 to 10 meters.

It is clear that at the both sites between the borehole B3 and of borehole B2 was operated a distributary paleochannel system of Selinous River up to 2600BP. According to Koutsios (2009) there was a stagnant body of water among the distributaries. This paleogeogrphic configuration suggests that the settlement was absent in the Selinous low delta plain because of the flood events and wetland environment. The ancient Helike was probably above the $20 \mathrm{~m}$-counter line.

\section{References}

Barsukov P O, Fainberg E B, Khabensky E O 2007. Shallow investigation by TEM-FAST technique: methodology and case histories. In Spichak V V (ed) Methods of geochemistry and geophysics. Elsevier. pp 55-77.

Kalisperi D. 2009. Assessment of groundwater resources in the north-central coast of Crete - Greece using geophysical and geochemical methods, PhD Thesis, Brunel University - UK.

Katsonopoulou D. 2005. The earthquake of 373 BC. Literary and archaeological evidence. Helike III, 15-32.

Kontopoulos N. \& Avramidis P. 2003. A late Holocene record of environmental changes from the Aliki lagoon, Egion, North Peloponnesus, Greece. Quaternary International, 111, 75-90.

Koukouvelas I.K. 1998. Transfer zones along active normal faults in Peloponnesus, Greece. Bull. Geol. Soc. Greece, 32, 221-229, 
Koukouvelas I.K \& T. Doutsos, 1996. Implication of structural segmentation during earthquakes: the 1995 Egion earthquake, Gulf of Corinth, Greece. J. Structural Geology, 18, 1381-1388.

Koutsios A. 2009. Middle to Late Holocene paleogeography of Helike delta plain. Application in Archaeological research. PhD Thesis, Univ. of Patras - GR

McNeill, D.J., Principles and applications of time domain electromagnetic techniques for resistivity soundings, Geonics, technical note TN 27, 1994

Missiaen T., Slob E. and Donselaar M.E., 2008, Comparing different shallow geophysical methods in a tidal estuary, Verdronken Land van Saeftinge, Western Scheldt, the Netherlands, Netherlands Journal of Geosciences Vol 87(2), pp.151 - 164.

Nabighian, M.N. and Macnae, J.C., Time domain electromagnetic prospecting methods. In: Nabighian, M.N.,Editor, 1991., Electromagnetic Methods in Applied GeophysicsApplications, vol. 2, SEG publication, Chap. 6., 1991, pp. 427-520

Poulimenos, G. 1993. Tectonics and sedimentation in the western Corinth graben. Neues Jb Geol. Paleont. Mh., 10, 607-630.

Soupios P., Kalisperi D., Kanta A., Kouli M., Barsukov P. and Vallianatos F., 2009, Coastal aquifer assessment based on geological and geophysical survey, North Western Crete, Greece, Environmental Earth Sciences, doi 10.1007/s12665-009-0320-1

Soter S. 1998. Holocene uplift and subsidence of the Helike delta, Gulf of Corinth, Greece, In: Stewart I. \& Vita-Finzi (eds) Coastal Tectonics, Spec. Pub. Geol. Soc. London, 146, 41-56.

Soter S. \& Katsanopoulou D., 2005. Studies on the geoarchaeology of the Helike Delta: 1991-2000. Helike III, 169-182.

TEM-RESearcher manual, Version 7, Applied Electromagnetic Research (AEMR), the Netherlands, 2007. 